\title{
Policy Making Process for Small Scale Food Industries Based on The Alternative Priority of Assistance Needs
}

\author{
Ibnu Wahid Fakhrudin Aziz, STP, MT *,1 \\ ${ }^{1}$ Department of Agroindustrial Technology, Faculty of Agricultural Technology \\ Universitas Gadjah Mada, Jl. Flora No.1 Bulaksumur 55281, Indonesia. \\ ibnu.wahid@gmail.com
}

\begin{abstract}
The industrial sector in Bantul, Yogyakarta potential is still dominated by small industries. There are lack of synergy between many parties, both government and private sectors in developing and empowering small businesses making it difficult to achieve the goal of creating small businesses are resilient and competitive. Thus, the need for a study of alternative priority needs of small industries which results can be used as a reference in formulating policy of development of the small industry. This analysis is used to make decisions effective output over the decision making process. The main tools Analytical Hierarchy Process (AHP) is a functional hierarchy with the main input of human perception. By hierarchy, a complex and unstructured problems solved in their groups, and the groups are arranged into a hierarchy form. Small industries were chosen as research sample includes melinjo chips industry, rice crackers industry, bakery industry, peyek cracker industry, and snack food industry. Food industries are scattered in the district of Bantul, Yogyakarta Province. The result was two things: (1) the ineffectiveness of the direction of development; (2) the lack of a uniform indicators of success, because each agency builder seeks to pursue the goals and targets in accordance with the criteria that they have set themselves. Factors that influence the activity / operating a small food industry in order are processes, products, labor, and then raw materials. The need for an industrial to an alternative support is the cornerstone of determining the appropriate policy applied to each different industries. Priority factors in every industry are factors that influence the selection of alternatives that may need assistance in the form of training, equipment, technical, capital and then marketing.
\end{abstract}

Keywords: Analytical Hierarchy Process, Policy making, Small Scale Food industries

\section{INTRODUCTION}

The industrial sector in Bantul, Yogyakarta potential is still dominated by small industries. Equal to $98 \%$ of the industry is a small industry and approximately $41.31 \%$ of the small industries engaged in food processing (BPS, 2007). With such large numbers, the small food industry has an important role to develop.

Attention to develop small industries at least based on three reasons. First, a small industry employs many workers and also intensive in use of local natural resources. Moreover, because of its location in the countryside, small industrial growth will lead to a positive impact on increasing the number of labor, reduction of poverty, equity in income distribution, and economic development in rural areas. In terms of policy, small industry clearly needs attention because it does not only provide income for most of the rural labor force, but also the frontline in the fight against poverty.

Current conditions indicate the lack of synergy between many parties, both government and private sectors in developing and empowering small businesses. Based on data of the Chamber of Commerce and Industry (Kadin) Indonesia reported by news agency ANTARA (March 9, 2010), in 2010 approximately IDR 80 trillion funds for SME's through 21 ministries are overlapped so that the focus is not used for the empowerment of SMEs.

In addition, the business development of small industry of course can not be separated from the various obstacles that are directly related to the small industry. These obstacles can arise from internal and external. Internal barriers include the financial, marketing, general 
management, labor, accounting and administration as well as production processes. This problem is related to work ethic, age, education, and traditions and new innovations absorption. External barriers between businessrelated organizations, distribution channels and marketing, technology and market access as well as unfair competition. This assistance may be realized through appropriate policies, which is absolutely in accordance with the conditions of the small industry.

Thus, the need for a study of alternative priority needs of small industries which results can be used as a reference in formulating policy of development of the small industry. The theoretical approach in determining the priority weight that is by analytical hierarchy process (AHP). AHP is a comprehensive model of decision-makers to take into account things that are qualitative and quantitative. Basically AHP is a method in detailing a complex situation, which is structured into a components (Saaty, 1986).

Analytical Hierarchy Process was first introduced by Thomas L. Saaty in his book "Desicion Making for Leader" in 1986. This analysis is used to make decisions effective output over the decision making process. Analytical Hierarchy Process (AHP) developed feelings and intuition and logic in a structured approach to decision-making.

The decision making process is basically choose an alternative. Analytical Hierarchy Process (AHP) is a method frequently used in the decision-making process. By hierarchy, a complex and unstructured problems solved in their groups, and the groups are arranged into a hierarchy form (Permadi in Suryadi, 1998).

\section{METHODOLOGY}

\subsection{Research Object}

This study was conducted on 36 small-scale food industry in Bantul, Yogyakarta in 2012

\subsection{Research Stages}

In this study, conducted research stages as follows:

\subsubsection{Objection setting}

This research aims to determine the factors that influence the activity / small industrial operations, determining the order of priority factors and develop small industry development policy is based on determining the factors that influence the activity of the small industry.

\subsubsection{Literature review}

The collection of data and information that supports research that comes from supporting books and literature about the small food industry and the theory of the Analytical Hierarchy Process (AHP). The purpose of literature is to find theoretical concepts that can help and support research.

\subsubsection{Preliminary observations}

These observations through surveys and interviews to a small industry players. In addition to consulting to experts (academics and practitioners) who understand the needs of a small industry. The aim of this preliminary observation is to provide a clearer view in research and approach to minimize the obstacles that may be found during the research.

\subsubsection{Factors Determination}

Determination of factors made of the results of the preliminary observations in the form of interviews with several sources and literature.

\subsubsection{Questionnaire Preparation}

The questionnaire is to know the opinion of the small industry players to factors that are supposed to influence and the needs of a small industry.

\subsubsection{Data Mining}

Data obtained by judgmental sampling through purposive principle is to select a sample based on certain considerations, conducted in the study area within a specified period. Primary data were obtained from a combination of questionnaires and interviews with small industry players while secondary data obtained 
from the literature, such as data from the Central Bureau of Statistics (BPS), offices and agencies, literature, scientific journals, papers, and other supporting materials.

\subsubsection{Processing and analysis of data}

The data that has been obtained is then processed and carried out an analysis of these data. Analysis carried out on the order of priority of the factors that influence the activity / small industrial operations with AHP method. Results of this analysis is used to formulate small business development policy is based on the determination of an appropriate alternative to the needs of the small industry.

\section{RESULT AND DISCUSSION}

Primary data have been obtained from interviews and questionnaires processed with the processing of analytical hierarchy process (AHP). Factors to consider are the factors of products, processes, labor, and raw materials.

Product factor is a factor that is determined by the business owner of output to be generated. This product factors include the number of products, product quality, product design in the form of packaging and form the desired product. Process factors are factors associated with production activities are carried out in production. These factors include the sustainability of production, production methods, and production equipment.

Sustainability of production is a factor related to the production process that takes place on an ongoing basis to meet the needs of the market. The production methods related to making the manufacture of a product carried by each business owner. The production equipment is a factor related to the technology used, either with conventional equipment and more advanced. Factors include the continuity of raw material supply of raw materials, raw material prices, and quality of raw materials.

As for alternative factors that made the object of alternative needs help for the industry is the operational needs of the industry in the form of capital assistance, equipment, skills training, empowering marketing and technical matters relating to the implementation of its business.

\subsection{Description of Objects Industry}

Small industry in Bantul district is dominated by small-scale agro-industries such as food and beverage industry, clothing from cloth and leather, leather goods, and furniture. The author in this study took samples of small food-based industry which is the largest number of industry in Bantul (CBS, 2007).

Small industries were chosen as research sample includes melinjo chips industry, rice crackers industry, bakery industry, peyek cracker industry, and snack food industry. Food industries are scattered in the district of Bantul, Yogyakarta Province.

Furthermore, the rice cracker industry in the village and village Plebengan Ponggok, Sidomulyo, Bambanglipuro, Bantul. Rice cracker business units in this area usually only to meet the local market consumption. Technological process used to be very simple. Bakery industry is the most widely spread in the district of Bantul.

Peyek Crackers Industry used as samples in the territory Imogiri, Palbapang and Pajangan, Bantul. Peyek Crackers industry is still a domestic industry that is still modest in terms of both process technology and in terms of product quality. The next object is snack food industry. The industry is located in some of the district of Bantul, including in Ngampilan, Sedayu, Pleret, Jetis, Sewon, Pandak, and Bambanglipuro. This industry produces several products such as yangko and pastries.

\subsection{Data dan Data Consistency Ratio}

The questionnaire has been filled and then tested to assess whether the answer sheets filled in the question fairly consistent. Consistency ratio indicates the level of consistency of respondents in providing an assessment of the elements. Results of the questionnaire was considered consistent if the consistency ratio $(\mathrm{CR}) \leq 0.1$.

The final results obtained and the number of questionnaires used in this study are as follows : 
Table 1. Number Questionnaires on each industry

\begin{tabular}{|c|l|c|}
\hline No & \multicolumn{1}{|c|}{ Industry } & Ammount \\
\hline 1 & Melinjo Chips & 5 \\
\hline 2 & Rice Crackers & 3 \\
\hline 3 & Bakery & 14 \\
\hline 4 & Peyek Crackers & 5 \\
\hline 5 & Snack Food & 9 \\
\hline
\end{tabular}

Description: The questionnaire inconsistent been replaced

\subsection{Weighted Priority Factor Calculation Result}

Weight calculation factor priority in this study to show how much influence each of the factors considered in determining the need for assistance. The calculation result can be seen in the following table :

Table 2. Priority Factor Weight Average

\begin{tabular}{|c|c|c|c|c|c|}
\hline \multirow[t]{2}{*}{ No } & \multirow[t]{2}{*}{ Industry } & \multicolumn{4}{|c|}{ Factor Types } \\
\hline & & Product & Process & Labor & $\begin{array}{c}\text { Raw } \\
\text { Material }\end{array}$ \\
\hline 1 & $\begin{array}{l}\text { Melinjo } \\
\text { Chips }\end{array}$ & 0.154 & 0.594 & 0.204 & 0.048 \\
\hline 2 & $\begin{array}{l}\text { Rice } \\
\text { Crackers }\end{array}$ & 0.263 & 0.463 & 0.211 & 0.064 \\
\hline 3 & Bakery & 0.516 & 0.289 & 0.054 & 0.142 \\
\hline 4 & $\begin{array}{l}\text { Peyek } \\
\text { Crackers }\end{array}$ & 0.358 & 0.146 & 0.426 & 0.070 \\
\hline 5 & $\begin{array}{l}\text { Snack } \\
\text { Food }\end{array}$ & 0.280 & 0.552 & 0.053 & 0.116 \\
\hline & Average & 0.3142 & $0.4088 *$ & 0.1896 & 0.088 \\
\hline
\end{tabular}

(*)the value of the highest priority weight

Priority weighting factors in industrial chips melinjo highest occupied by process factors (0.594). This happens because the chips melinjo industry this whole process is still manual and simple so that the workload is still very high. Furthermore, the second priority is the labor factor $(0.204)$, which is still very limited skills.

In the rice cracker industry, the priority weight that ranks first factor is a factor of the process (0.463). It is theoretically demonstrated that the orientation of craftsmen in the industry is a rice cracker production activities are carried out, which include continuity of production, production methods, and production equipment.

Priority weighting factors in the bakery industry which ranks first is a factor of the product $(0.516)$.. They expect innovation in packaging can extend the shelf life of products produced today. Furthermore, the second priority in the bakery industry is a factor of the process $(0.289)$ is still lacking in terms of modern equipment.

Peyek industry, the weight of labor (0.426) occupies the highest priority. This fits the current state of labor requires sellers to distribute the products to a wider market. Limited market because only local area limiting this industry to grow. Furthermore, the second priority is a factor dent industrial products (0.358) are still lacking a touch of innovation in terms of product design and packaging.

Weighting factors in the snack food industry is the highest rank is the factor of the process (0.552). This process factors closely related to the continuity of production, methods of processes performed, and the process equipment used. Furthermore, the second priority is product factor $(0.280)$ which is the average in the market that is most manufacturers produce similar products.

Furthermore, based on the average value of the overall value of each factor will be the highest priority conclusion of the factors, as stated in the figure below :

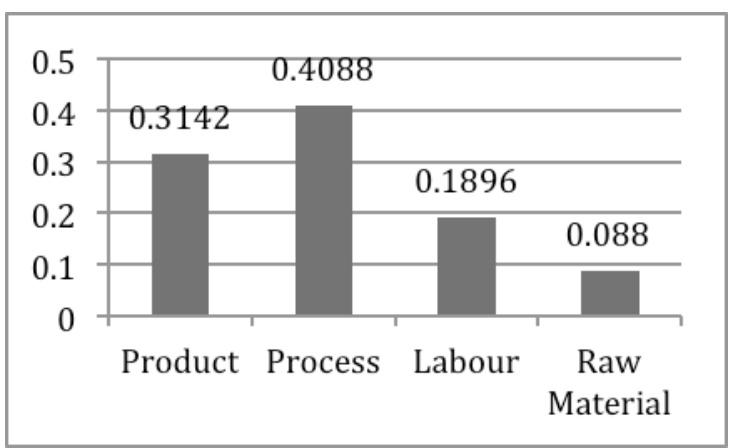

Figure 1. Comparison of Weighted Factor Priority

\subsection{Priority Alternative Calculation Result Weight}


Alternative capital requirement associated with the requirement that the form of money (loans etc) as working capital. Alternative equipment needs associated with the need for means of production are closely related to touch technology. Alternative marketing empowerment requirements associated with efforts to acquire or develop marketing channels existing marketing channels.

Based on the calculation, priority weighting alternative to the needs of each industry as well as the average weight of the whole industry an alternative priorities as presented in the following table :

Table 3. Priority Alternative Weight Average

\begin{tabular}{|c|c|c|c|c|c|c|}
\hline \multirow[b]{2}{*}{$\begin{array}{l}\mathbf{N} \\
\mathbf{0}\end{array}$} & \multirow[b]{2}{*}{ Industry } & \multicolumn{5}{|c|}{ Alternative Assitance Needs } \\
\hline & & 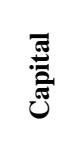 & 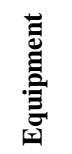 & 兰 & 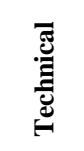 & 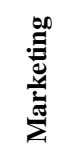 \\
\hline 1 & $\begin{array}{l}\text { Melinjo } \\
\text { Chips }\end{array}$ & 0.099 & 0.283 & 0.410 & 0.158 & 0.050 \\
\hline 2 & $\begin{array}{l}\text { Rice } \\
\text { Crackers }\end{array}$ & 0.104 & 0.423 & 0.292 & 0.134 & 0.048 \\
\hline 3 & Bakery & 0.122 & 0.225 & 0.243 & 0.340 & 0.070 \\
\hline 4 & $\begin{array}{l}\text { Peyek } \\
\text { Crackers }\end{array}$ & 0.287 & 0.268 & 0.156 & 0.059 & 0.231 \\
\hline 5 & $\begin{array}{l}\text { Snack } \\
\text { Food } \\
\end{array}$ & 0.116 & 0.218 & 0.423 & 0.182 & 0.061 \\
\hline & Average & 0.1456 & $\begin{array}{c}0.283 \\
4 \\
\end{array}$ & $\begin{array}{c}0.304 \\
8^{*} \\
\end{array}$ & 0.1746 & 0.092 \\
\hline
\end{tabular}

(*)the value of the highest priority weight

At melinjo chips industry, the calculation results show the industry chose priority weight training aid (0.410) to improve the skills to support the production process better. Currently one of the obstacles is the product of these chips can not be consumed by all consumers, especially the elderly who are aged above 40 years due to health reasons.

Consuming raw material chips melinjo can increase uric acid levels can lead to gout disease is pain in the joints. The next priority is support equipment (0.283) which is considered today still have a high workload. The third priority is technical assistance (0.158), the fourth is the capital (0.099), and the last is a marketing support (0.050).
In the rice cracker industry, industrial owners prefer assistance in the form of equipment (0.423) is needed. It is theoretically proved the value of the highest priority weight. Currently on rice crackers idustri still using simple tools. With the use of proper equipment is expected to improve the quality of the product and can further increase sales turnover.

Peyek crackers industry on the top priority of the owners of the industry is expecting capital (0.287). The location is in remote rural housing conditions are still very modest. Furthermore, the second priority is aid equipment (0.268), the third priority is help marketing channels (0.231), the fourth priority is training aid (0.156), and the last priority is the assistance of a technical nature (0.059).

In the snack food industry, the choice of the owner is aid in the form of training (0.423), which can improve their skills in terms of process technology and product innovation. Furthermore, the second priority is aid equipment (0.218), the third priority is aid that is technical stuff (0.182), the fourth priority is an alternative capital (0.116), and the last alternative is the marketing support (0.061).

Furthermore, taking the average value of the overall value of the value of each alternative will be the highest priority alternative conclusions that should be taken in small food industry in general, as stated in Figure 2 below:

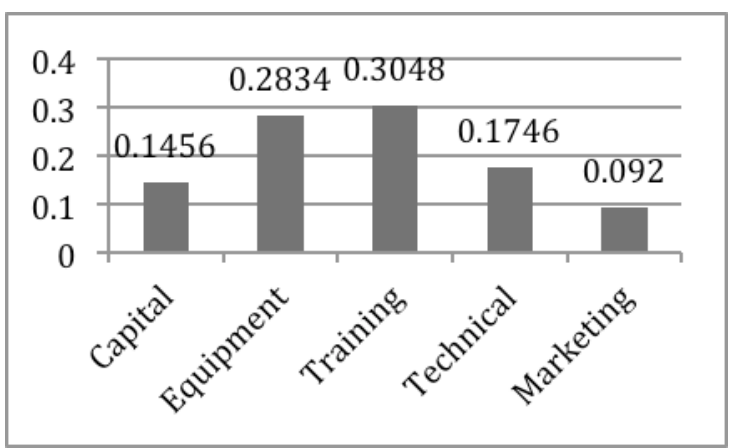

Figure 2. Comparison Chart Weight Average Priorities

\subsection{Recommendations Policy}

In general, most of the current state of small industries that exist just to survive alone. The result was two things: (1) the ineffectiveness of 
the direction of development; (2) the lack of a uniform indicators of success, because each agency builder seeks to pursue the goals and targets in accordance with the criteria that they have set themselves.

The calculation result theoretically and supported by direct observations then proposed some specific suggestions that are implemented later as policies that support the development of small industries such food. Policies that can be applied can be:

a. Transfer knowledge about the technology of food processing and food safety;

b. Provide training on creativity and product development;

c. Assist product development through the control of food-standard equipment;

d. Provision of knowledge about the technology and design of packaging standards of food safety;

e. Providing information on legal aspects of product certification;

f. Facilitating product distribution channels, and

g. Capital granting business loans with low interest.

\section{CONCLUSION}

From the data analysis and discussion conducted several conclusions can be drawn as follows:

1. Factors that influence the activity / operating a small food industry in outline form factor products, processes, labor, and raw materials. The order of priority factors for small-scale food industry in general can be seen in the following table :

Table 4. Priority factor in the Small Scale Food Industry

\begin{tabular}{|l|c|c|c|c|}
\hline \multirow{2}{*}{ Industry } & \multicolumn{4}{|c|}{ Priority factor } \\
\cline { 2 - 5 } & $1^{\mathrm{ST}}$ & $2^{\mathrm{ND}}$ & $3^{\mathrm{RD}}$ & $4^{\mathrm{TH}}$ \\
\hline $\begin{array}{l}\text { Small Scale } \\
\text { Food Industry }\end{array}$ & Process & Product & Labour & $\begin{array}{c}\text { Raw } \\
\text { Material }\end{array}$ \\
\hline
\end{tabular}

2. Priority factors in every industry are factors that influence the selection of alternatives that may need assistance in the form of capital, equipment, training, technical, and marketing. Table presents the following order of priority which needs the help of the selected alternative small-scale food industry in general:
Table 5. Alternative Priority Assistance to Small Scale Food Industry

\begin{tabular}{|c|c|c|c|c|c|}
\hline \multirow{2}{*}{ Industry } & \multicolumn{5}{|c|}{$\begin{array}{c}\text { Alternative Priority } \\
\text { Assistance }\end{array}$} \\
\hline & $1^{\mathrm{ST}}$ & $2^{\mathrm{ND}}$ & $3^{\mathrm{RD}}$ & $4^{\mathrm{TH}}$ & $5^{\mathrm{TH}}$ \\
\hline $\begin{array}{l}\text { Small Scale } \\
\text { Food Industry }\end{array}$ & 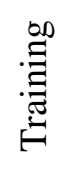 & 营 & 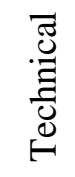 & 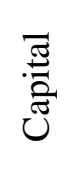 & 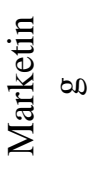 \\
\hline
\end{tabular}

\section{REFERENCES}

Anonim. 2008. Bantul dalam Angka 2008. Badan Pusat Statistik Kabupaten Bantul. Bantul

Djarwanto dan Pangestu Subagyo. 1990. Statistik Induktif. BPFE. Yogyakarta.

Erickson, B.H. dan T.A. Nosanchuk,. 1987. Memahami Data (Statistika untuk Ilmu Sosial). LP3ES. Jakarta.

Forman, Ernest H. and Mary Ann Selly, 2001, Decision by Objectives.

Gaspersz, Vincent,. 1992. Analisis Sistem Terapan. Tarsito. Bandung

Mangkusubroto, K. dan C.L. Trisnadi. 1978. Analisa Keputusan : Pendekatan Sistem dalam Manajemen dan Proyek. Ganeca Exact. Bandung.

Perwitasari, Yudita,. 1999. Upaya Pengembangan Industri Kecil Kerajinan Bambu Melalui Identifikasi FaktorFaktor Kelayakan Usaha. Skripsi. Jurusan TIP. FTP UGM. Yogyakarta.

Saaty, Thomas L,. 1986. Decisions Making for Leader : The Analitical Hierarchy Process for Decisions in A Complex World. RWS Publications. Pittsburgh.

Suryadi, Kadarsan dan Ramdhani Ali. 1998. Sistem Pendukung Keputusan : Suatu Wacana Idealisasi dan Implementasi Konsep Pengambilan Keputusan. PT Remaja Rosdakarya. Bandung. 